\title{
Soil moisture mediated interaction between Polygonatum biflorum and leaf spot disease
}

\author{
Robert J. Warren II • Erin Mordecai
}

Received: 13 April 2009/Accepted: 8 December 2009/Published online: 24 December 2009

(C) The Author(s) 2009. This article is published with open access at Springerlink.com

\begin{abstract}
Fungal pathogens can regulate the abundance and distribution of natural plant populations by inhibiting the growth, survival, and reproduction of their hosts. The abiotic environment is a crucial component in host-pathogen interactions in natural plant populations as favorable conditions drive pathogen development, reproduction, and persistence. Foliar plant pathogens, such as fungal lesions referred to generically as "leaf spot disease," are particularly responsive to increased moisture levels, but the manner in which the abiotic environment drives disease dynamics, and how these diseases regulate natural plant populations, is not fully understood. We investigate (1) the impact of ambient soil moisture and diffuse light on the prevalence of a leaf spot pathogen (Phyllosticta sp.) in a natural population of Polygonatum biflorum, an understory herb native to deciduous forest understories in the eastern US, and (2) the effects of the fungal pathogen on the survival, growth, and abundance of the plants. We tracked six
\end{abstract}

R. J. Warren II ( $₫)$

Yale School of Forestry and Environmental Studies, 205 Prospect Street, New Haven, CT 06511, USA

e-mail: hexastylis@gmail.com

E. Mordecai

Department of Ecology, Evolution, and Marine Biology, University of California, Santa Barbara, CA 93106, USA

e-mail: emordecai@gmail.com
$P$. biflorum populations and disease incidence, as well as soil moisture and diffuse light, between 2003 and 2005 in the understory deciduous forest of the southern Appalachian Mountains, North Carolina, USA. Results show that both the occurrence of P. biflorum and the prevalence of $P$. biflorum leaf spot disease are highest where soil moisture is intermediate and diffuse light is lowest. Disease occurrence depends upon plant presence, but it also adversely impacts plant survival, abundance, and growth. These results suggest that leaf spot disease is likely to impact population dynamics, which in turn vary as a function of environmental drivers.

Keywords Disease ecology - Population dynamics . Biotic interactions - Perennial herb .

Fungal pathogen - Southern Appalachian Mountains · Polygonatum biflorum . Phyllostica $\mathrm{sp}$

\section{Introduction}

Fungal pathogens can regulate the abundance and distribution of natural plant populations by inhibiting the growth, survival, and reproduction of their hosts (Alexander 1992; Dobson and Crawley 1994; Gilbert 2002; Harper 1977; Holmes 1996; Jarosz and Davelos 1995; Kranz 1990). Despite the ubiquitous presence of plant pathogens and their deleterious effect on the seeds, flowers, leaves, and overall function of plants, the influence of fungal disease on natural populations 
often has been overlooked in population studies (Gilbert 2002), and the preponderance of interest into plant-pathogen dynamics has centered upon commercial crops rather than on wild species (Burdon and Chilvers 1982; Dinoor and Eshed 1984). Growing concerns about habitat degradation and the impacts of climate change on plant populations have brought heightened attention toward in situ disease hostpathogen dynamics (Garrett et al. 2006; Holmes 1996).

Burdon (1993) suggested that a discrepancy between agricultural and ecological disease research, and the chosen target populations for study, creates widely divergent assessments of disease impacts on plant populations. The catastrophic plant disease outbreaks observed in agricultural systems are uncommon in relatively undisturbed wild plant populations (Dinoor and Eshed 1984; Kranz 1990), but ongoing epidemics are commonplace (Burdon 1993; Gilbert 2002). Further, extinctions in natural populations from foliar pathogens also appear uncommon as the virulence is not typically catastrophic and plant resistance is widespread (Alexander and Antonovics 1995; Dinoor and Eshed 1984; Jarosz and Davelos 1995). The population-level impact can be cumulative, however, as disease loads are often density dependent (Burdon and Chilvers 1982) and outbreaks are accompanied by a loss in plant fitness, such as decreases in survival and reproduction (Alexander 1992). Habitat fragmentation, exotic pathogens, and climate change also can shift host-pathogen dynamics to extremes that induce the loss of one or both (Garrett et al. 2006; Holmes 1996; Kranz 1990).

The abiotic environment is a crucial component in host-pathogen interactions in natural plant populations. Favorable temperature and moisture conditions drive pathogen development, reproduction, and persistence (De Wolf and Isard 2007; Feil et al. 2003; Garrett et al. 2006; Laine 2008). Foliar plant pathogens, such as fungal lesions referred to generically as "leaf spot disease," are particularly responsive to increased moisture levels (De Wolf et al. 2003; Emery and English 1994; Nirenberg et al. 2002; Tomioka et al. 2008). The dispersal of fungal pathogens depends on spore recruitment, which is greatly enhanced by precipitation (Agrios 2005; Campbell and Madden 1990; Geagea et al. 1999). Under favorable moisture and temperature conditions, foliar fungal pathogens can undergo several generations per growing season and produce dramatic numbers of spores per lesion (Jarosz and Davelos 1995). The potential for extensive spore production and widespread dispersal ability may give these pathogens greater ability to reach potential habitats than their host species, and colonization may only be limited by host presence (Campbell and Madden 1990; Dinoor and Eshed 1984; Jarosz and Davelos 1995).

The way in which the abiotic environment drives disease dynamics, and how these diseases regulate natural plant populations, is not fully understood (Mitchell and Power 2006). Lowered fitness due to pathogenic buildup could lead to the decline of host species in habitats that favor pathogens (Alexander and Holt 1998; Burdon 1993; Burdon and Chilvers 1982), even if those habitats also favor the physiological requirements of the hosts. Classic niche theory predicts that species perform best at intermediate physiological optima for resources such as soil moisture (Hutchinson 1957, 1959; MacArthur and Levins 1967; Whittaker 1975); however, all species may have physiological optima at the upper end of a resource gradient but decline due to increased competition and predation (Connell 1961; Grime 1963; Keddy 1989). The natural distributions of several understory herbaceous plants in the deciduous forests of the eastern United States are highest at intermediate soil moisture levels (Diez and Pulliam 2007; Warren 2007), yet they respond vigorously to augmented soil moisture when transplanted into experimental plots (Warren 2007). This suggests that biotic interactions, not physiological tolerance, limit the plants where soil moisture is high in natural distributions.

We investigate whether the interaction between a fungal pathogen, Phyllosticta sp., and an understory herb, Polygonatum biflorum, is mediated by environmental conditions. Our objectives are to assess how both the fungal pathogen and herbaceous host respond to abiotic gradients and investigate the effects of the Phyllosticta sp. pathogen on the survival, growth, and abundance of $P$. biflorum. Given that fungal pathogens respond with vigor to moisture, we expect (1) increasing incidence of the pathogen as a function of soil moisture and (2) decreasing plant performance and survival as a function of the pathogen. 


\section{Materials and methods}

Study site and species

Data for this research were collected as part of a larger demographic study of understory herbaceous plants in the southeastern United States (for full details see Diez 2005; Diez and Pulliam 2007; Giladi 2004; Warren 2007). Six $20 \times 24 \mathrm{~m}$ demography grids were established in 1999 at the Coweeta Hydrologic Laboratory (CWT) in the Nantahala National Forest $\left(35^{\circ} 03^{\prime} \mathrm{N}\right.$ latitude, $83^{\circ} 25^{\prime} \mathrm{W}$ longitude, 750-1025 m elevation) in Otto-Macon County, North Carolina, USA. All the grids were located in relatively mature ( $\sim 80$ years old) deciduous forest. Each P. biflorum plant $(n=1997)$ was individually flagged and tracked between 1999 and 2006. The presence or absence of leaf spot disease $(n=319)$ was recorded in 2003 and 2004. A subset of plants $(n=382)$ was tracked in 2005 to determine whether the absence of diseased plants was due to death or dormancy.

Polygonatum biflorum (Walter) Elliot is a perennial understory herbaceous plant common in the deciduous forests of the mid-western and eastern United States and eastern Canada. Individuals in the natural populations of $P$. biflorum at the study sites often have yellow-to-brown leaf spots caused by fungal infection. The leaf spot disease was identified as a species of the Phyllosticta genus at the University of Georgia Plant Pathology Department by Peter Ojiambo. Ojiambo cultured infected $P$. biflorum leaf tissue and identified pycnidia (resting fruit bodies) of Phyllosticta spp. Phyllosticta spp species commonly infect plants in the Polygonatum genus (Anderson and Anderson 1921; Farlow and Seymour 1888; Kellerman 1885; Motohashi et al. 2009)

\section{Abiotic monitoring}

Within each grid, 16 "intensive" cells were utilized for abiotic monitoring. The volumetric soil moisture percentage was measured with a handheld Hydrosense Soil Water Content Measurement System (Campbell Scientific, Inc.). The probe uses a pair of $12-\mathrm{cm}$ rods inserted into the soil to estimate volumetric moisture content through dielectric permittivity (how an electric field effects and is affected by a medium). Measurements were taken at each intensive cell every 2 weeks through 2004, and seasonally through 2006. Percent photosynthetically active radiation (PAR, wavelength: $400-700 \mathrm{~nm}$ ) was calculated as the percentage of light from the fully exposed reference site reaching the grid sites. The understory grid measurements were taken with a 0.5-m handheld AccuPAR ceptometer (Decagon Devices, Inc.), and the reference measurements were taken with a Li-200 spherical PAR sensor (LiCor, Inc.). Measurements were taken seasonally on cloudy days between 10 am and 2 pm to minimize inter-grid variation in solar zenith angle intermittent sunflecks (Gendron et al. 1998; Messier and Puttonen 1995; Parent and Messier 1996).

Data analysis

Plant abundance was calculated at the number of $P$. biflorum plants per cell, and leaf spot disease (Phyllosticta sp.) incidence was calculated as the proportion of infected plants per total plants per cell (with disease recoded as present or absent per individual plant). While disease incidence research often quantifies the intensity of disease load per individual, our research focused on host-pathogen interactions at the population level and as a function of environmental drivers, which were measured at the aggregate (cell) rather than individual scale. Expressing disease incidence as the proportion of individual plant tissue affected minimizes or eliminates aggregate-scale variation in disease incidence (Burdon and Chilvers 1982), and this would obfuscate variance at the scale we measured the environmental variables.

The abundance of $P$. biflorum plants and the proportion of plants infected by leaf spot disease were analyzed as functions of environmental variables using Generalized Linear Mixed Models (GLMMs) through restricted maximum likelihood. By employing mixed model with grid location as a random effect, we accounted for spatial autocorrelation deriving from the measurement of plant performance and environmental drivers in cells nested within grids. The generalized linear model structure also incorporates non-normally distributed data through link functions which accounts for the error in plant count data, which rarely follows a normal distribution. The GLMMs were fit using the Laplace approximation in the "lme4" package for the "R" statistical program (R Development Core Team 2005) assuming a 
Poisson error distribution for plant abundance and a binomial error distribution for the proportion infected with leaf spot disease. We evaluated the models based on the inclusion or exclusion of fixed effects (soil moisture and diffuse light, second-order fixed effect terms (to account for unimodal responses), and interaction terms. Model selection was based on the Akaike information criterion (AIC) (see Burnham and Anderson 2002), except when overdispersion was detected, in which case we used quasi-AIC (QAIC), which is a modified AIC that divides the loglikelihood by the overdispersion scale parameter of the full model (Bolker et al. 2009). The AIC method selects models based on the explanatory variables with penalties for over specification.

We checked for potential collinearity in the fixed effects by assessing the variance inflation factors (from the covariance matrix of parameter estimates) for the covariates using the "Design" package in the " $\mathrm{R}$ " statistical program (R Development Core Team 2005). The variance inflation factors for soil moisture and diffuse light in the plant and diseases models were $<5.0$, which indicates that they independently predict variance in the response variables (Kutner et al. 2004). An assumption of both Poisson and binomial error distributions is that the mean and variance are equal, resulting in a dispersion parameter ( $\phi=$ deviance/residual degrees of freedom) approximating 1 . We checked for overdispersion $(\phi>1)$ in both models and found that the plant abundance data were overdispersed $(\phi=5.41)$. This was accounted for by using the quasi-Poisson error distribution and quasi-AIC model selection.

Plant survival was calculated as the presence or absence of $P$. biflorum plants in 2004 that were present in 2003. Growth was calculated as the change in P. biflorum leaf number between 2003 and 2004. Student's $t$-tests were used to determine the significance of differences in mean plant survival and growth between cells where leaf spot disease was present in 2003 and cells where it was absent. In order to ensure that plants absent in 2004 were deceased and not dormant, a subsample of the missing plants was checked in 2005 for reappearance, which indicated dormancy rather than death in 2004. The abundance of $P$. biflorum (per cell) in 2004 was analyzed using a generalized linear model in which the proportion of plants (per cell) infected with leaf spot in 2003 was the covariable assuming a Poisson error distribution and $\log$ function. As graphing indicated nonlinear responses, a second-order term was explored.

\section{Results}

Generalized Linear Mixed Model fitting based on AIC and weighted AIC suggested that no terms should be dropped from the plant abundance model: abundance $\sim$ soil moisture - soil moisture ${ }^{2}+$ diffuse light - diffuse light ${ }^{2}+$ moisture:light $+\mid$ grid. The positive first-order and negative second-order soil moisture and diffuse light coefficients indicated that $P$. biflorum abundance in natural populations peaked at intermediate levels of the environmental drivers (Fig. 1, Table 1a). The slope of all coefficients differed significantly from 0 except for the interaction term. Similarly, model fitting suggested that no terms should be dropped from the disease prevalence model: plants infected $\sim$ soil moisture - soil moisture ${ }^{2}-$ diffuse light - diffuse $\quad$ light ${ }^{2}+$ moisture:light $+\mid$ grid.
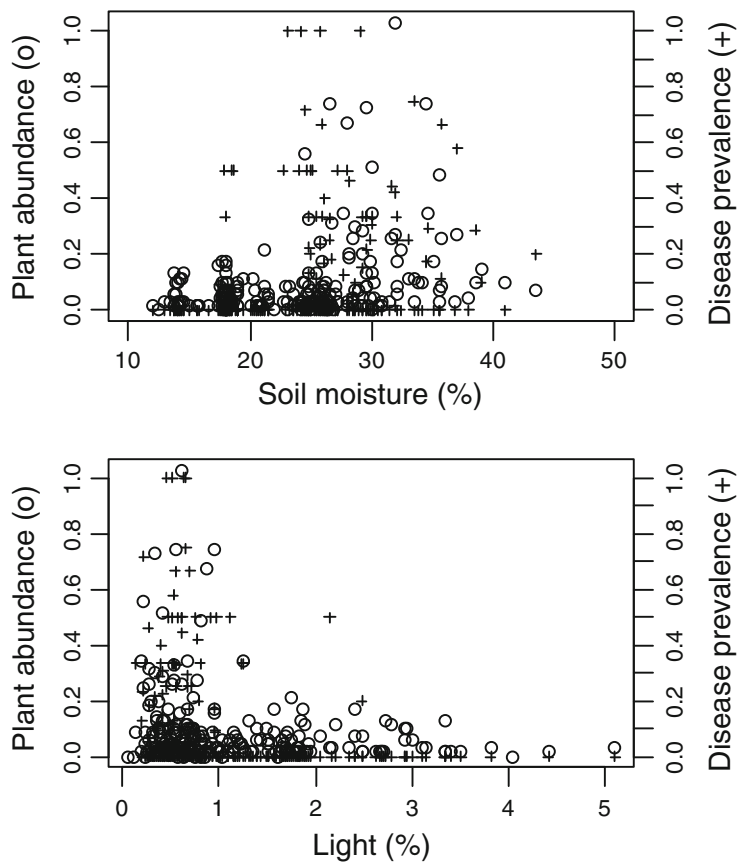

Fig. 1 The relative Polygonatum biflorum abundance (abundance/total abundance, per $1 \mathrm{~m}^{2}$ cell) and leaf spot disease (Phyllosticta sp.) prevalence (diseased plants/all plants, per $1 \mathrm{~m}^{2}$ cell) as a function of percent soil moisture and diffuse light. Plant abundance is indicated by "o," and disease prevalence is indicated by "+" 
Table 1 Generalized linear mixed models of plant abundance (a) and leaf spot disease prevalence (b) as functions of soil moisture and diffuse light

\begin{tabular}{|c|c|c|c|}
\hline \multicolumn{4}{|c|}{ a Plant abundance } \\
\hline Coefficient & Estimate & SE & $t$-value \\
\hline Intercept & -4.014 & $1.109 * * *$ & $-3.169 * * *$ \\
\hline Soil moisture & 0.369 & 0.076 & $4.847 * * *$ \\
\hline Soil moisture $^{2}$ & -0.006 & 0.001 & $-5.081 * * *$ \\
\hline Diffuse light & 0.883 & 0.283 & $3.126^{* *}$ \\
\hline Diffuse light ${ }^{2}$ & -0.268 & 0.054 & $-4.826^{* * *}$ \\
\hline Moisture:light & 0.037 & 0.008 & $1.027^{\mathrm{ns}}$ \\
\hline \multicolumn{4}{|c|}{ b Disease prevalence } \\
\hline Coefficient & Estimate & $\mathrm{SE}$ & z-value \\
\hline Intercept & 8.570 & 3.816 & $2.246 *$ \\
\hline Soil moisture & -0.629 & 0.260 & $-2.416^{*}$ \\
\hline Soil moisture $^{2}$ & 0.008 & 0.004 & $2.020 *$ \\
\hline Diffuse light & -3.234 & 1.119 & $-2.889 * *$ \\
\hline Diffuse light ${ }^{2}$ & -0.354 & 0.404 & $-0.876^{\mathbf{n s}}$ \\
\hline Moisture:light & 0.097 & 0.039 & $2.464 *$ \\
\hline
\end{tabular}

Second-order terms were included to account for unimodal responses. Plant abundance was analyzed using a generalized linear mixed model with grid location as a random effect and a quasi-Poisson error distribution; disease prevalence (proportion of infected plants per cell) was analyzed using a generalized linear mixed model with grid location as a random effect and a binomial error distribution

Significance codes: $* * * p<0.001, * * p<0.01, * p<0.05$; "." $=0.1$; ns not significant

However, disease prevalence peaked at intermediate soil moisture levels but decreased at all levels of diffuse light (Fig. 1, Table 1b). The slope of all coefficients differed significantly from 0 except for diffuse light ${ }^{2}$. The interaction term indicated that the effects of soil moisture and diffuse light were not additive; light had little effect where soil moisture was high, but the proportion of diseased plants decreased with light where soil moisture was low.

Mean P. biflorum survival in 2004 was significantly lower in plants that had leaf spots in 2003 than those that did not $(t=4.17, \mathrm{~d} f=118.76, p<0.001)$ (Fig. 2). Approximately 55\% of the plants that had leaf spot disease in 2003 survived to 2004, while approximately $75 \%$ of the plants without the disease in 2003 survived to 2004 . However, $75 \%$ of the plants that appeared deceased in 2004 reappeared in 2005. Plants that had leaf spots in 2003 also grew significantly less in 2004 than uninfected plants $(t=4.17$,

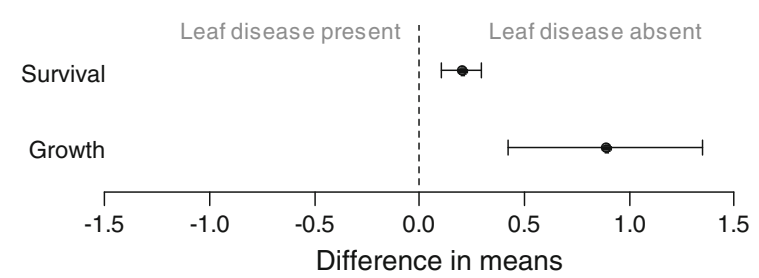

Fig. $2 t$-distributions and $95 \%$ confidence interval for the difference in the 2004 survival and growth of plants infected and not infected in 2003. The positive values and intervals indicate that survival and growth were significantly higher in plants not infected

$\mathrm{d} f=118.76, p<0.001)$. Many $P$. biflorum plants in the study populations had fewer leaves in 2004 than 2003 ( $-0.52 \pm 3.65$ leaves), but plants with leaf spot disease lost $1.36 \pm 2.27$ leaves between 2003 and 2004, while those without leaf spots lost $0.46 \pm 3.71$ leaves.

The 2004 abundance of P. biflorum decreased significantly as a function of the proportion of 2003 plants infected per cell (coefficient $=-8.61, z$-value $=$ $-13.33, p<0.0001$ ) (Fig. 3). The significant secondorder term $\quad($ coefficient $=15.69, \quad z$-value $=8.96$, $p<0.0001$ ) indicated that the decrease leveled out at approximately $60 \%$ disease prevalence and increased somewhat at the highest disease rate. The model explained a great deal of variance $\left(R^{2}=65.7 \%\right)$ in $P$. biflorum abundance.

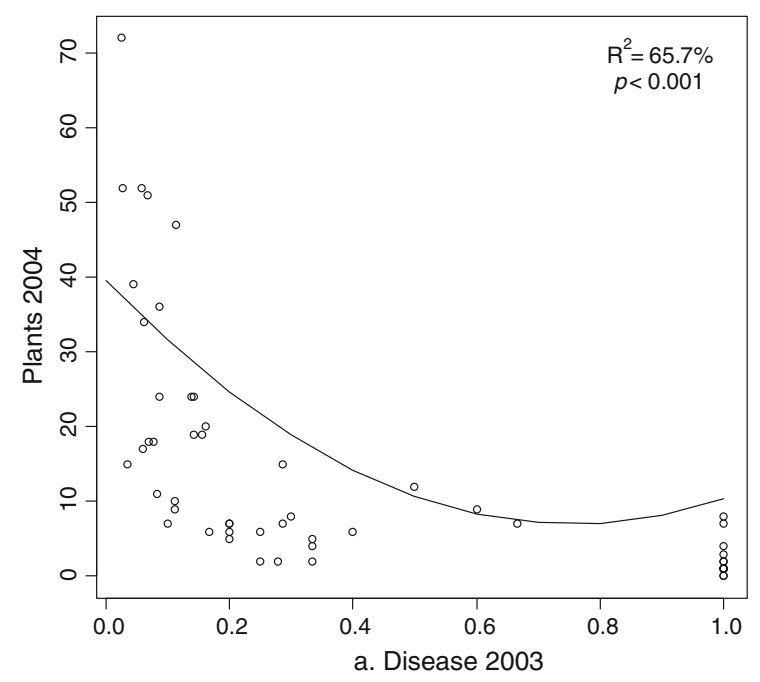

Fig. 3 Relationship between Polygonatum biflorum abundance (per $1 \mathrm{~m}^{2}$ cell) in 2004 as a function of the proportion of leaf spot (Phyllosticta sp.) and infected plants (per $1 \mathrm{~m}^{2}$ cell) in 2003 


\section{Discussion}

Our results show that the abundance of $P$. biflorum and the prevalence of leaf spot disease are highest where soil moisture is intermediate (Fig. 1, Table 1). The abundance of $P$. biflorum also peaks where diffuse light is intermediate but leaf spot disease declines as a function of light, particularly where soil moisture is low (Fig. 1, Table 1). Leaf spot disease occurrence depends upon $P$. biflorum plants, but it also causes adverse affects such as decreased survival, abundance and growth (Figs. 2, 3). These results suggest that the disease impacts individual plants in ways that are likely to impact population dynamics. These interactions vary as a function of environmental drivers, particularly soil moisture.

The reproduction and infection rate of fungal pathogens increases with temperature and soil moisture (Emery and English 1994; Nirenberg et al. 2002), and the occurrence of plant-infecting anthracnose species are most prevalent in warm, wet microhabitats (Chellemi and Britton 1992; Chellemi et al. 1992; Daughtrey and Hibben 1994). Fungal plant pathogens disperse through microscopic spores which are transported after being discharged into the air or picked up by precipitation (Agrios 2005; Geagea et al. 1999). As the Phyllostica sp. leaf spot disease depends on $P$. biflorum occurrence (as well as other understory herb hosts (Anderson and Anderson 1921; Kellerman 1885)), the similarity in soil moisture responses may simply reflect the correlation between disease and host. Plant abundance is highest in $25-35 \%$ soil moisture, and disease prevalence is highest in 20-35\%; and while both decrease where diffuse light $>1 \%$, disease prevalence drops off steeply, but plant abundance tapers down to $2-3 \%$ (Fig. 1). While $P$. biflorum did not occur in great abundance where light levels were highest, leaf spot disease was almost always absent, suggesting relatively high light or the associated effects (e.g., decreased humidity) makes $P$. biflorum unsuitable habitat in some conditions. The leaf spot disease generally tracks $P$. biflorum density, which suggests the same environmental factors drive both disease incidence and plant density. Host density has been shown to increase pathogen spread and incidence (Alexander 1992; Alexander and Holt 1998), but a rigorous assessment of density dependence requires more than the 2 years of data to analyze the iterations between host and pathogen. The apparent preference of both disease and plant for moist conditions does suggest that the leaf spot disease may regulate the plants with increased prevalence where soil moisture is highest.

Polygonatum biflorum survival and growth is lower in plants previously infected with leaf spot disease, and subsequent plant abundance decreases where disease prevalence was highest. The survival of individual plants infected with the disease decreases approximately $20 \%$, and growth decreases approximately $66 \%$. However, dormancy is common in understory plants (Lesica and Steele 1994; Shefferson et al. 2005; Warren 2007), and 75\% of the "deceased" 2004 $P$. biflorum plants infected in 2003 reappeared in 2005. Dormancy is a cost response strategy to endure environmental or life stage stress, acting as a tradeoff with survival (Primack and Stacy 1998; Shefferson et al. 2005). Phyllosticta sp. infections create large areas with depressed photosynthesis on infected leaves (Aldea et al. 2006), and the subsequent loss in carbon gain would likely retard growth and may induce dormancy. The reappearance of once-infected plants suggests that leaf spot disease is more costly in terms of growth than survival, making it more a burden than eradicator of $P$. biflorum plants, which is consistent with the low rate of disease-induced extinctions in wild plant populations (Alexander and Antonovics 1995; Dinoor and Eshed 1984; Jarosz and Davelos 1995).

Leaf lesions similar to those found on P. biflorum also have been observed on neighboring Uvularia perfoliata L. and Maianthemum racemosum (L.) Link (Warren, pers. obs.), also Phyllostica hosts (Anderson and Anderson 1921; Kellerman 1885), suggesting that leaf spot disease population dynamics may depend on multiple species. Moreover, the interaction between P. biflorum and Phyllosticta spp. may reflect additional biotic interactions that depend on soil moisture. For example, leaf herbivory is a crucial pathway for effective pathogenic leaf infections (García-Guzmán and Benítez-Malvido 2003; Garcia-Guzman and Dirzo 2001), and herbivory intensity may reflect soil moisture gradients as well as fungal dynamics. While presence and abundance data are revealing, longerterm demographic data including life stage transitions and reproductive success, would be far more revealing 
of host-pathogen dynamics. Experimental manipulations of pathogen presence and density, as well as augmentation of the abiotic environment to explore the interaction of soil moisture and light, would decouple the contributions of microclimate factors to plant density and disease prevalence.

\section{Conclusions}

Classic niche theory suggests that species occupy different microhabitats (Hutchinson 1957, 1959; MacArthur and Levins 1967), resulting in unimodal (bell-shaped) responses along resource gradients where species perform best at their resource optima (Bigelow and Canham 2002; Whittaker 1975). However, evidence that all species resource responses are unimodal is mixed (Austin et al. 1990), and decreased performance at the highest resource levels may reflect biotic interactions (e.g., competition) rather than selflimitation (Connell 1961; Grime 1963; Keddy 2001; Keddy and Shipley 1989). The evidence here suggests that the unimodal response of the understory herbaceous plant along soil moisture gradients is consistent with physiology (drought tolerance) at the low end and biotic interactions (leaf spot disease) at the high end, much the same as Connell's classic delineation of barnacle niches (Connell 1961). Connell (1975) suggested that abiotic factors are critical at the harsh end of environmental gradients, and biotic interactions become important where resources are plentiful. While biotic interactions have historically been defined by competition, our results suggest that parasitic interactions could also explain herbaceous distributions at high soil moisture levels. That is, increased leaf spot disease may regulate plant abundance where soil moisture is highest as a function of optimal environmental conditions and/or increased host density.

Acknowledgments This research was supported by NSF grants to $\mathrm{H}$. Ronald Pulliam (DEB-0235371) and to the Coweeta LTER program (DEB-9632854 and DEB-0218001). Research was conducted at the Coweeta Hydrological Laboratory near Otto, N.C. and at Whitehall Forest, University of Georgia property managed by the D. B. Warnell School of Forest Resources. The authors would like to thank H. Ronald Pulliam, Scott Eustis, Hanh Nguyen, and Seth Wenger for manuscript input, and Jeff Diez and Itamar Giladi for their participation in the larger project.
Open Access This article is distributed under the terms of the Creative Commons Attribution Noncommercial License which permits any noncommercial use, distribution, and reproduction in any medium, provided the original author(s) and source are credited.

\section{References}

Agrios GN (2005) Plant pathology. Academic Press, San Diego, CA

Aldea M, Hamilton JG, Resti JP, Zangerl AR, Berenbaum MR, Frank TD, DeLucia EH (2006) Comparison of photosynthetic damage from arthropod herbivory and pathogen infection in understory hardwood saplings. Oecologia 149:221-232

Alexander H (1992) Fungal pathogens and the structure of plant populations and communities. In: Carroll G, Wicklow D (eds) The fungal community: its organization and role in the ecosystem. Marcel Dekker, Inc., New York, pp 481-497

Alexander HM, Antonovics J (1995) Spread of anther-smut disease (Ustilago-Violacea) and character correlations in a genetically variable experimental population of Silene Alba. J Ecol 83:783-794

Alexander H, Holt R (1998) The interaction between plant competition and disease. Perspect Plant Ecol Evol Syst $1: 206-220$

Anderson HW, Anderson PJ (1921) The parasitic fungi of Montgomery County. In: Payne F (ed) Proceedings of the Indiana Academy of Science. Indiana University, Bloomington, IN, USA, pp 175-222

Austin MP, Nicholls AO, Margules CR (1990) Measurement of the realized qualitative niche-environmental niches of 5 eucalyptus species. Ecol Monogr 60:161-177

Bigelow SW, Canham CD (2002) Community organization of tree species along soil gradients in a north-eastern USA forest. J Ecol 90:188-200

Bolker BM, Brooks ME, Clark CJ, Geange SW, Poulsen JR, Stevens MH, White JS (2009) Generalized linear mixed models: a practical guide for ecology and evolution. Trends Ecol Evol 24:127-135

Burdon J (1993) The structure of pathogen populations in natural plant communities. Annu Rev Phytopathol 31: 305-323

Burdon J, Chilvers G (1982) Host density as a factor in plant disease ecology. Annu Rev Phytopathol 20:143-166

Burnham KP, Anderson DR (2002) Model selection and multimodel inference: a practical information-theoretic approach. Springer-Verlag, New York

Campbell CL, Madden LV (1990) Introduction to plant disease epidemiology. Wiley, New York

Chellemi DO, Britton KO (1992) Influence of canopy microclimate on incidence and severity of dogwood anthracnose. Can J Botany-Revue Canadienne De Botanique 70:1093-1096

Chellemi DO, Britton KO, Swank WT (1992) Influence of site factors on dogwood anthracnose in the Nantahala MountainRange of western North-Carolina. Plant Dis 76:915-918 
Connell JH (1961) The influence of interspecific competition and other factors on the distribution of the barnacle Chthamalus stallatus. Ecology 42:710-723

Connell JH (1975) Some mechanisms producing structure in natural communities: a model and evidence from field experiments. In: Cody ML, Diamond JM (eds) Ecology and evolution of communities. Harvard University Press, Cambridge, MA, pp 460-490

Daughtrey ML, Hibben CR (1994) Dogwood anthracnose-a new disease threatens 2 native Cornus species. Annu Rev Phytopathol 32:61-73

De Wolf ED, Isard SA (2007) Disease cycle approach to plant disease prediction. Annu Rev Phytopathol 45:203-220

De Wolf ED, Madden LV, Lipps PE (2003) Risk assessment models for wheat Fusarium head blight epidemics based on within-season weather data. Phytopathology 93: $428-435$

Diez JM (2005) Ecological dynamics of a terrestrial orchid symbiosis. Institute of Ecology. University of Georgia, Athens, GA

Diez JM, Pulliam HR (2007) Hierarchical analysis of species distributions across environmental gradients. Ecology 88:3144-3152

Dinoor A, Eshed N (1984) The role and importance of pathogens in natural plant-communities. Annu Rev Phytopathol 22:443-466

Dobson A, Crawley W (1994) Pathogens and the structure of plant-communities. Trends Ecol Evol 9:393-398

Emery KM, English JT (1994) Development of foliar diseases of alfalfa in relation to microclimate, host growth, and fertility. Phytopathology 84:1263-1269

Farlow WG, Seymour AB (1888) A provisional host-index of the fungi of the United States. Cambridge, Cambridge, MA

Feil WS, Butler EE, Duniway JM, Gubler WD (2003) The effects of moisture and temperature on the survival of Colletotrichum acutatum on strawberry residue in soil. Can J Plant Pathol-Revue Canadienne De Phytopathologie 25:362-370

García-Guzmán G, Benítez-Malvido J (2003) Effect of litter on the incidence of leaf-fungal pathogens and herbivory in seedlings of the tropical tree Nectandra ambigens. J Trop Ecol 19:171-177

Garcia-Guzman G, Dirzo R (2001) Patterns of leaf-pathogen infection in the understory of a Mexican rain forest: incidence, spatiotemporal variation, and mechanisms of infection. Am J Botany 88:634-645

Garrett KA, Dendy SP, Frank EE, Rouse MN, Travers SE (2006) Climate change effects on plant disease: genomes to ecosystems. Annu Rev Phytopathol 44:489-509

Geagea L, Huber L, Sache I (1999) Dry-dispersal and rainsplash of brown (Puccinia recondita f.sp tritici) and yellow ( $P$-striiformis) rust spores from infected wheat leaves exposed to simulated raindrops. Plant Pathol 48:472-482

Gendron F, Messier C, Comeau PG (1998) Comparison of various methods for estimating the mean growing season percent photosynthetic photon flux density in forests. Agric For Meteorol 92:55-70

Giladi I (2004) The role of habitat-specific demography, habitat-specific dispersal, and the evolution of dispersal distances in determining current and future distributions of the ant-dispersed forest herb, Hexastylis arifolia. University of Georgia, Athens, Georgia

Gilbert GS (2002) Evolutionary ecology of plant diseases in natural ecosystems. Annu Rev Phytopathol 40:13-43

Grime JP (1963) Factors determining the occurrence of calcifuge species on shallow soils over calcareous substrata. J Ecol 51:375

Harper JL (1977) Population biology of plants. Academic Press, New York

Holmes JC (1996) Parasites as threats to biodiversity in shrinking ecosystems. Biodiv Conserv 5:975-983

Hutchinson GE (1957) Population studies-animal ecology and demography—concluding remarks. Cold Spring Harb Symp Quant Biol 22:415-427

Hutchinson GE (1959) Homage to Santa-Rosalia or why are there so many kinds of animals. Am Nat 93:145-159

Jarosz AM, Davelos AL (1995) Effects of disease in wild plant-populations and the evolution of pathogen aggressiveness. New Phytol 129:371-387

Keddy PA (1989) Competition. Chapman \& Hall, London

Keddy PA (2001) Competition. Kluwer, Dordrecht

Keddy PA, Shipley B (1989) Competitive hierarchies in herbaceous plant-communities. Oikos 54:234-241

Kellerman WA (1885) A partial list of the Kansas parasitic fungi, together with their host plants. In: Science KAo (ed) Transactions 16th and 17th of the annual meetings of the Kansas academy of science. Kansas Publishing House, Topeka, KS, USA, pp 79-86

Kranz J (1990) Tansley review no 28 fungal diseases in multispecies plant-communities. New Phytol 116:383-405

Kutner MH, Nachtsheim CJ, Neter J (2004) Applied linear regression models. McGraw-Hill Irwin, New York

Laine AL (2008) Temperature-mediated patterns of local adaptation in a natural plant-pathogen metapopulation. Ecol Lett 11:327-337

Lesica P, Steele BM (1994) Prolonged dormancy in vascular plants and implications for monitoring studies. Nat Areas J 14:209-212

MacArthur R, Levins R (1967) Limiting similarity convergence and divergence of coexisting species. Am Nat 101:377-385

Messier C, Puttonen P (1995) Spatial and temporal variation in the light environment of developing scots pine standsthe basis for a quick and efficient method of characterizing light. Can J For Res-Revue Canadienne De Recherche Forestiere 25:343-354

Mitchell CE, Power AG (2006) Disease dynamics in plant communities. In: Collinge S, Ray C (eds) Disease ecology: community structure and pathogen dynamics. Oxford University Press, New York

Motohashi K, Inaba S, Anzai K, Takamatsu S, Nakashima C (2009) Phylogenetic analyses of Japanese species of phyllosticta sensu stricto. Mycoscience 50:291-302

Nirenberg HI, Feiler U, Hagedorn G (2002) Description of Colletotrichum lupini comb. nov in modern terms. Mycologia 94:307-320

Parent S, Messier C (1996) A simple and efficient method to estimate microsite light availability under a forest canopy. Can J For Res-Revue Canadienne De Recherche Forestiere 26:151-154 
Primack R, Stacy E (1998) Cost of reproduction in the pink lady's slipper orchid, (Cypripedium acaule, Orchidaceae): an eleven-year experimental study of three populations. Am J Bot 85:1672-1679

R Development Core Team (2005) R: a language and environment for statistical computing. R Foundation for Statistical Computing, Vienna, Austria

Shefferson RP, Kull T, Tali K (2005) Adult whole-plant dormancy induced by stress in long-lived orchids. Ecology 86:3099-3104
Tomioka K, Moriwaki J, Sato T (2008) Anthracnose of Polygonatum falcatum caused by Colletotrichum dematium. J Gen Plant Pathol 74:402-404

Warren RJ (2007) Linking understory evergreen herbaceous distributions and niche differentiation using habitat-specific demography and experimental common gardens. University of Georgia, Athens, GA

Whittaker RH (1975) Communities and ecosystems. MacMillan, New York 